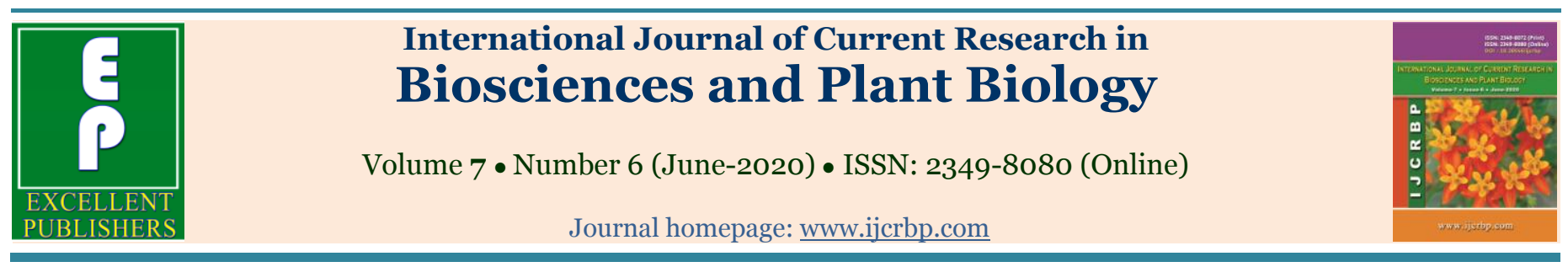

\title{
Phytochemical constituents and mineral composition of fruits of Solanum melongena and Cucumis sativus
}

\author{
Chinedu Imo*, Sunday Michael Abu, Ozioma Prince Emmanuel and \\ Khadiyat Sanda Yusuf
}

\author{
Department of Biochemistry, Faculty of Pure and Applied Sciences, Federal University Wukari, \\ P.M.B. 1020, Wukari, Taraba State, Nigeria \\ ${ }^{*}$ Corresponding author; e-mail: chineduo4@yahoo.com; Telephone: +234-8037505543
}

\begin{tabular}{|c|c|}
\hline Article Info & ABSTRACT \\
\hline $\begin{array}{l}\text { Date of Acceptance: } \\
23 \text { May } 2020\end{array}$ & \multirow{4}{*}{$\begin{array}{l}\text { This study investigated the phytochemical constituents and mineral composition of } \\
\text { fruits of Solanum melongena and Cucumis sativus. The two fruits where purchased in } \\
\text { Wukari, Nigeria. They were sun-dried and ground to a fine powder. Ethanol was used } \\
\text { for the extraction of the phytochemical constituents. The phytochemical and mineral } \\
\text { analyses were carried out with the use of GCMS and AAS respectively. The result } \\
\text { showed that a wide range of phytochemicals with various functions were suggested to } \\
\text { be present in the ethanolic extracts of Solanum melongena fruit and Cucumis sativus } \\
\text { fruit. Cucumis sativus fruit contain higher level of magnesium and copper than } \\
\text { Solanum melongena fruit, but contain lower level of calcium, manganese, chromium, } \\
\text { zinc and iron than Solanum melongena fruit. This study showed the various } \\
\text { importance of the two fruits in pharmacology and general medicine due to the presence } \\
\text { of some important phytochemical constituents and mineral elements in the fruits. }\end{array}$} \\
\hline & \\
\hline Keywords & \\
\hline $\begin{array}{l}\text { Co-factor } \\
\text { Cucumis sativus } \\
\text { Mineral } \\
\text { Phytochemical }\end{array}$ & \\
\hline
\end{tabular}

\section{Introduction}

Solanum melongena (egg plant) is an essential vegetable in the family of Solanaceae that is well consumed in Colombian Caribbean (Murrugo et al., 2017). In Africa, over 200 species of Solanum are identified, with about 25 species found in Nigeria (Gbile and Adesina, 1988). Solanum melongena is one of the most important vegetable crops with over 1.7 million hectares being cultivated across the globe annually with China having the highest production capacity of about 17.03 million metric tons/annum, while Turkey ranks fourth with 880,000 metric tons/annum (Faik et al., 2015). It is an economically useful crop in Asia, Africa, India, Central America and in some warm temperate regions of the Mediterranean and South America (Sihachkr et al., 1993). Several varieties of Solanum melongena show a considerable difference in the fruit shapes and colours, ranging from eggshaped to long club-shaped and from white, yellow, green through degrees of purple pigmentation to almost black (Mohammed et al., 2010). The crop has the ability to relatively resist drought stress as compared to the other members of the Solanaceae family 
(Karam et al., 2011; Juan, 2015) and thrives well in the soil nourished with nitrogen resulting in high fruit yield and weight (Mohammed et al., 2010). Various parts of this plant have been previously used in the treatment of inflammatory conditions, cardiac debility, neuralgia, ulcers of nose, cholera, bronchitis and asthma in the Indian traditional medicinal system (Warrier et al., 1996). The fruit extract demonstrated antihaemorrhoidal and hypotensive effect collaborating the use of the ashes of the peduncle in the treatment of intestinal haemorrhages, piles and toothache (Diab et al., 2011). The antipyretic and analgesic effect of Solanum melongena leaves extracts as demonstrated by Mutalik et al. (2003) further supported the claims by traditional medicine practitioners in the use of the leaves extract against fever. Similarly, the n-hexane leaves, fruit and stem extracts have been demonstrated to show antioxidant property (Irda et al., 2017).

Cucumis sativus (Cucumber) is a member of Cucurbitaceae family such as squash, luffas, melon, watermelon, pumpkin and zucchini which is widely cultivated (Vivek et al., 2017) and consumed fresh or in the form of salads (Sotiroudis et al., 2010) in most part of the world, including Nigeria. The plant is a creeping vine that bears cylindrical fruits that are used as culinary vegetables (Robert et al., 2018). Cucumis sativus has the greatest economic importance out of the 30 species of Cucumis, while the most important cucumber cultivars originate from Europe, America, western part of India, China and the Himalayas (Zieliński and Zielińska, 2017). Several varieties of cucumber have been used for years for their anti-inflammatory benefits on treating skin disorders, soothing properties for digestion and other therapeutic uses in the traditional medicinal system (Murad and Nye, 2016). The Fruit is also considered very useful for weight loss and traditionally, the seeds were used to expel the intestinal worms and tapeworms
(Hina and Anam, 2017). The antimicrobial activity of the extracts of the various parts (seed, leaves and fruits) of this plant has also been demonstrated scientifically (Sood et al., 2012; Osuagwu and Ejikeme, 2015). The hypoglycemic and hypolipidemic effects of the ethanol leaves extract of cucumber were evident when Sharmin et al. (2017) noticed a significant improvement on the diabetic condition induced by alloxan on rats.

Considering how widely the two plant parts used in this study are consumed worldwide, there is need to ascertain their phytochemical constituents and mineral composition. This warrants research into the present study.

\section{Materials and methods}

\section{Plant materials used}

The fruits of Solanum melongena and Cucumis sativus were purchased in Wukari, Nigeria. The fruits were identified at the Biological Science Department, Federal University Wukari, Nigeria. The two fruits were sun-dried, ground into powder with the use of a manual blender.

\section{Preparation of plant extracts}

The powder of each of the fruits was macerated in ethanol (70\%) for 48 hours with occasional shaking. It was later filtered and the filtrate concentrated (with elimination of the ethanol) using rotary evaporator. The concentrated crude fruit extracts were then used for phytochemical analysis.

\section{Determination of phytochemical constituents and mineral composition of fruits of Solanum melongena and Cucumis sativus}

The phytochemical analysis was carried out with the use of GC (model No. 7890B) and MS detector (model 5977A) using the method described by Imo et al. (2018). The amount of 
the selected minerals in the samples were carried out with the use of atomic absorption spectroscopy (model AA28oFS), product of Agilent Technologies, U.S.A.

\section{Results and discussion}

Table 1. Phytochemical constituents of ethanolic extract of Cucumis sativus fruit.

\begin{tabular}{|c|c|c|}
\hline Name of compound & Retention time (min) & Area \% \\
\hline Hydrazine, ethyl- & 50.49 & 5.44 \\
\hline 1,5-Heptadiene, (E)- & 56.17 & 23.67 \\
\hline 10-Azido-1-decanethiol & 56.89 & 5.00 \\
\hline Actinobolin & 57.64 & 2.05 \\
\hline Propargyl alcohol & 58.23 & 0.43 \\
\hline Cyclopropaneethanol & 58.61 & 0.84 \\
\hline Hydrazine, 1,2-dimethyl- & 59.27 & 0.75 \\
\hline o-Allylhydroxylamine & 64.14 & 0.41 \\
\hline 11-(2-Cyclopenten-1-yl)undecanoic acid, (+)- & 65.81 & 2.98 \\
\hline Formic acid hydrazide & 67.07 & 0.51 \\
\hline Propanal, oxime & 71.67 & 0.46 \\
\hline Amyl nitrite & 75.11 & 1.34 \\
\hline 7-Octenoic acid & 76.82 & 0.65 \\
\hline 9-Octadecenal & 77.23 & 0.62 \\
\hline 2,4-Dimethyl-3-nitrobicyclo[3.2.1] octan-8-one & 77.91 & 0.45 \\
\hline 1,9-Decadiene & 78.35 & 0.79 \\
\hline cis-3-Nonen-1-ol, pentafluoropropionate & 79.20 & 1.32 \\
\hline .alpha.-D-Glucopyranose, 4-O-.beta.-D-galactopyranosyl- & 79.83 & 0.46 \\
\hline Oxirane, (7-octenyl)- & 80.60 & 1.27 \\
\hline .alpha.-D-Galactopyranoside, methy & 81.38 & 0.62 \\
\hline 2-Heptenoic acid, 7-(methylenecyclopropyl)-, methyl ester & 82.18 & 1.79 \\
\hline 3,4 -Altrosan & 83.09 & 4.37 \\
\hline Cyclopentaneundecanoic acid & 83.92 & 1.94 \\
\hline Hexanoic acid, 6-hydroxy- & 84.41 & 2.92 \\
\hline Lactose & 84.78 & 0.69 \\
\hline Dodecanoic acid, 1-methylethyl ester & 85.24 & 4.05 \\
\hline Methyl 4,6-ethylidene-.alpha.-d-galactopyranoside & 86.15 & 3.63 \\
\hline Tetradecanoic acid & 86.61 & 1.58 \\
\hline Sucrose & 86.98 & 1.97 \\
\hline 1-Bromo-3-(2-bromoethyl)-nonane & 87.38 & 1.56 \\
\hline Methyl d-glycero-.beta.-d-gulo-heptoside & 87.91 & 2.79 \\
\hline Glucose & 88.86 & 1.96 \\
\hline 2-Octyn-1-ol & 89.23 & 0.96 \\
\hline Undecanoic acid & 90.44 & 2.65 \\
\hline Polygalitol & 90.99 & 0.54 \\
\hline D-erythro-Pentose, 2-deoxy- & 91.27 & 1.15 \\
\hline 9-Oxononanoic acid & 91.91 & 1.21 \\
\hline 1-Hexyn-3-ol & $93 \cdot 31$ & 1.20 \\
\hline Trimethylsilyl-di(timethylsiloxy)- silane & 96.05 & 1.33 \\
\hline Malic acid, 3 TBDMS derivative & 97.78 & 2.06 \\
\hline
\end{tabular}




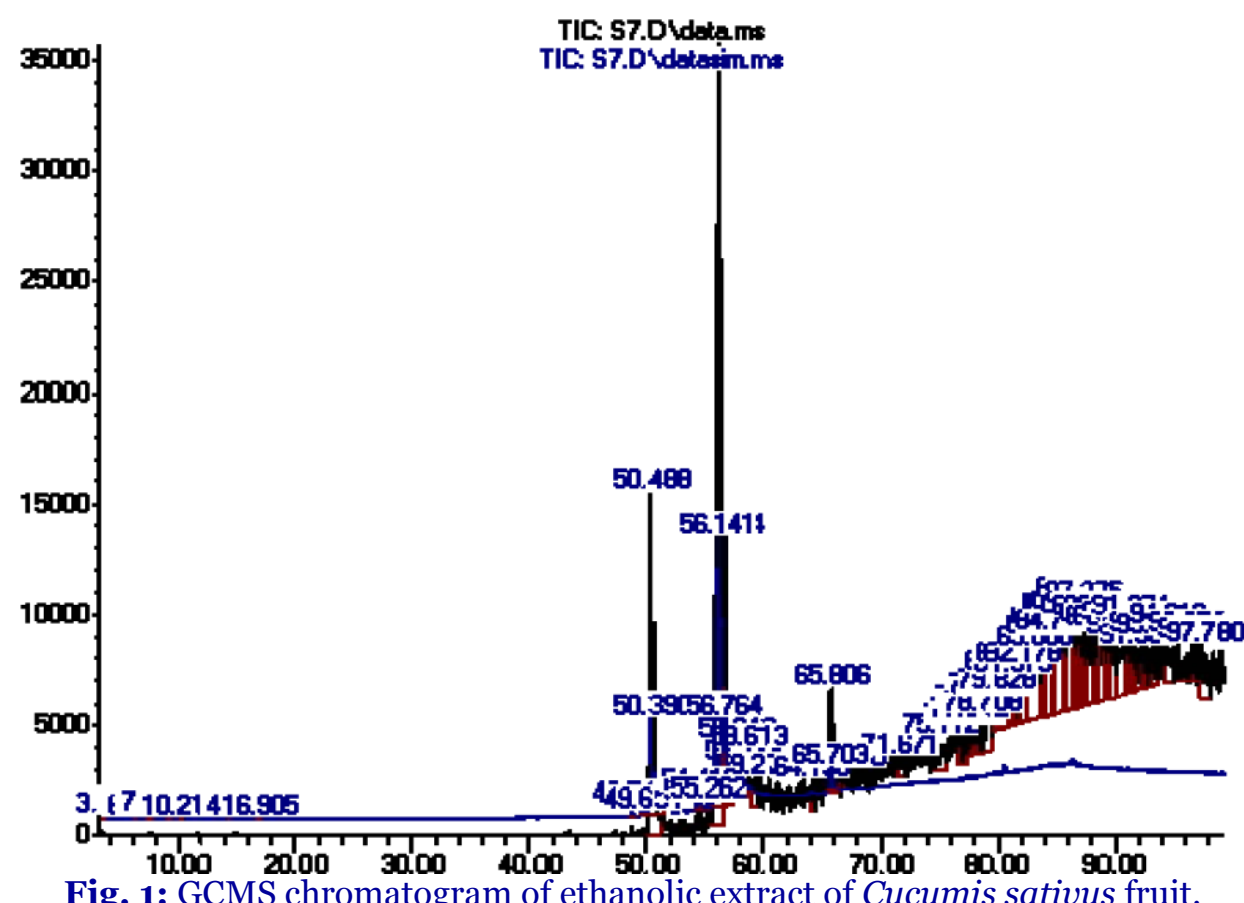

Table 2. Phytochemical constituents of ethanolic extract of Solanum melongena fruit.

\begin{tabular}{lll}
\hline Name of compound & Retention time (min) & Area \% \\
\hline 3,3,3-Trifluoropropene & 4.88 & 0.31 \\
2-Propenenitrile & 21.76 & 3.60 \\
Furoxan-4-amine, 3-(1,2,4-oxadiazol-3-yl)- & 41.12 & 0.12 \\
Propiolonitrile & 41.63 & 0.38 \\
Hexanoic acid, 6-bromo- & 50.50 & 5.43 \\
Oxirane, 3-butenyl- & 56.17 & 19.96 \\
o-Allylhydroxylamine & 57.11 & 4.81 \\
Formic acid hydrazide & 58.64 & 0.80 \\
Pyridine, 2,3,4,5-tetrahydro- & 60.58 & 0.27 \\
1-Propanol & 61.28 & 0.37 \\
Urea & 62.13 & 0.31 \\
Acetic acid, (aminooxy)- & 62.93 & 0.23 \\
Difluoramine & 63.66 & 0.31 \\
Hydrazine, 1,2-dimethyl- & 64.18 & 0.77 \\
Cyclopropane, methylmethylene- & 65.03 & 0.13 \\
Carbamic acid,2-(2-tolyloxycarbonylamino)ethyl ester & 65.86 & 6.93 \\
1,2-Dimethyl cyclopropane & 66.84 & 0.16 \\
Cyclobutane, methylene- & 67.73 & 1.23 \\
Pent-2-ynal & 68.59 & 0.19 \\
1-Azabicyclo[3.1.o]hexane & 70.13 & 0.25 \\
Silanamine, N-silyl- & 70.87 & 0.22 \\
Ethyl isocyanide & 72.23 & 0.70 \\
4-Cyclopentene-1,3-diol, trans- & 72.81 & 0.42 \\
Acetonitrile, 2,2'-iminobis- & 73.82 & 0.96 \\
Thiirane & 75.37 & 1.72 \\
Ethane, methoxy- & 77.01 & 0.85 \\
Undecanoic acid, 10-bromo- & 77.60 & 0.65 \\
D-Mannopyranose & 78.59 & 1.20 \\
9-Octadecenal & 79.80 & 1.48 \\
Sucrose & 85.64 & 27.12 \\
Pterin-6-carboxylic acid & 92.69 & 9.92 \\
Undecanoic acid & 97.55 & 2.81 \\
\hline
\end{tabular}




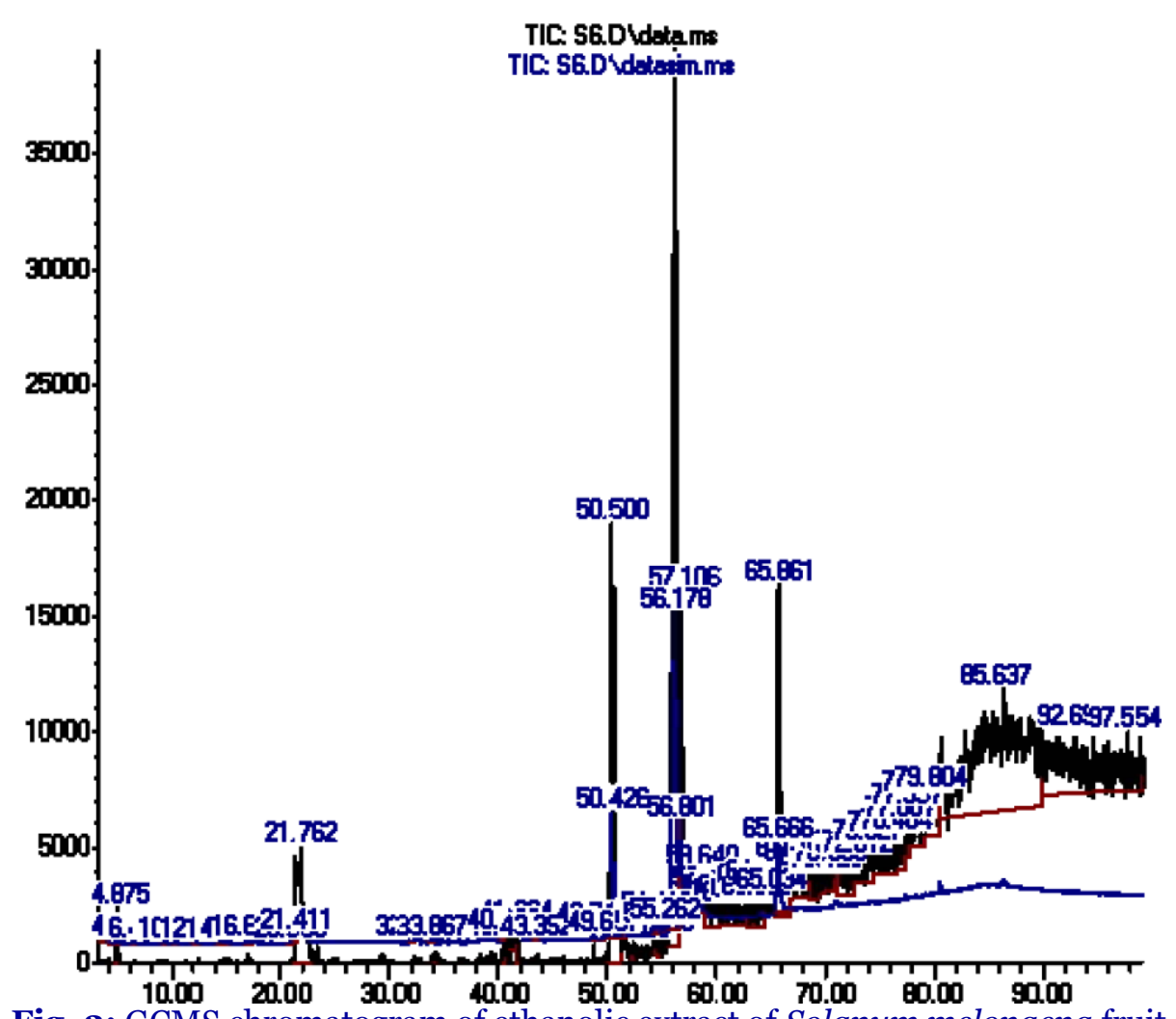

Fig. 2: GCMS chromatogram of ethanolic extract of Solanum melongena fruit.

Table 3. Mineral composition of Cucumis sativus fruit and Solanum melongena fruit (ppm).

\begin{tabular}{llc}
\hline Mineral & Cucumis sativus fruit & Solanum melongena fruit \\
\hline Magnesium & $10.437 \pm 0.0015$ & $8.671 \pm 0.0016$ \\
Calcium & $17.621 \pm 0.0012$ & $20.292 \pm 0.0006$ \\
Manganese & $0.001 \pm 0.0014$ & $0.003 \pm 0.0010$ \\
Chromium & $0.488 \pm 0.0014$ & $0.886 \pm 0.0014$ \\
Copper & $7.122 \pm 0.0012$ & $0.057 \pm 0.0015$ \\
Zinc & $3.958 \pm 0.0017$ & $5.592 \pm 0.0011$ \\
Iron & $1.001 \pm 0.0005$ & $1.388 \pm 0.0018$ \\
\hline Values are mean \pm standard deviation $(n=3)$. &
\end{tabular}

Cucumis sativus fruit contain higher level of magnesium and copper than Solanum melongena fruit, but contain lower level of calcium, manganese, chromium, zinc and iron than Solanum melongena fruit.

A wide range of phytochemicals were suggested to be present in the ethanolic extract of Cucumis sativus fruit (Table 1) and the ethanolic extract of Solanum melongena fruit (Table 2). Actinobolin exhibit antibiotic property and has been reported to be inhibitory in vitro for cariogenic Streptococci and a strong cariostatic activity in vivo, appears to exert a bacteriostatic effect on Streptococcus faecalis (Hunt and Narkates, 1971). Propargyl alcohol is a clear colourless liquid which has a geranium-like odour. It has been reported to be used for making other chemicals, as a soil fumigant and a corrosion inhibitor (Lewis, 2001). o-Allylhydroxylamine which was detected in the two plant extracts evaluated has been reported to possess antimicrobial activity against Plasmodium falciparum (Prado-Prado et al., 2010). Formic hydrazide was also detected in both plant extracts. It was reported to be used in the synthesis of 1,2,4-triazole derivatives (Zong et 
al., 2005) and of new anticancer agent, 6- $\mathrm{N}$ formylamino-12,13-dihydro-1,11-dihydroxy-13( $\beta$ - $D$-glucopyranosyl)-5H-indolo[2,3- $a]-$

pyrrolo $[3,4-c]$ carbazole-5,7 $(6 H)$-dione (Ohkubo et al., 1997).

Amyl nitrite is employed medically in the treatment of heart diseases as well as angina. It is also used sometimes as an antidote for cyanide poisoning (Giannini et al., 1982). 9Octadecenal which was detected in the two plant extracts and cis-3-Nonen-1-ol (compound) are food additives (flavouring agents). 9-Oxononanoic acid is a mediumchain oxo-fatty acid. It has a role as an acetylCoA carboxylase inhibitor. It is an aldehydic acid, an omega-oxo fatty acid and a mediumchain fatty acid (Ren et al., 2013). Undecanoic acid is a flavouring and an antifungal agent. It has been reported to be a medium chain length monocarboxylic acid which may be involved in controlling triacylglycerol synthesis (Hornung et al., 1992). The study of Varsha et al. (2014) reported that 3,4-Altrosan possess a bacteriostat fungicide activity. Sucrose, glucose and lactose are important sugars used in the food industry and for pharmaceutical products (Gerrit et al., 2014). Tetradecanoic acid which is also known as myristic acid is used in the food industry as a flavour ingredient (Burdock and Crabin, 2007). It is also used industrially in the synthesis of soaps and cosmetics (Lewis, 2007). 1-Hexyn-3-ol may be used in the synthesis of racemic $3^{-}$ hydroxy-2-hexanone. It is reported to be used in the production or preparation of 1,2,3triazoles (Sharba et al., 2011).

2-Propenenitrile, which is also known as Acrylonitrile is reported to be reactive and toxic at low doses (Brazdil, 2012) and is believed to increase cancer in high dose. Aminooxyacetic acid is a compound which has been reported to inhibit the activity of 4aminobutyrate aminotransferase (GABA-T) in vitro and in vivo, thereby leading to less gamma-aminobutyric acid (GABA) being broken down (Wallach, 1961). Ethyl isocyanate is used for pesticide intermediate and pharmaceutical (Lewis, 2001). Ethane, methoxy-, also known as ethyl methyl ether, is a colourless gaseous ether with a medicine-like odour. Its inhalation may cause asphyxiation or dizziness (Haynes, 2010). Mannose is known to be important in human metabolism (Freeze and Sharma, 2010). It is believed that the use of ethanolic extracts of Cucumis sativus and Solanum melongena fruits may exhibit or play a role in aiding the functions reported for its phytochemical constituents.

The consumption of foods which are rich in mineral elements promotes the supply of the individual mineral elements which may help boost the immune system and sustain life (Imo et al., 2018). Minerals are essential for sustaining life and the proper functioning of human immune system (Soetan et al., 2010; Imo et al., 2018). The level of magnesium in both fruits showed that their consumption will aid certain enzyme activities such as in glycolysis and DNA/RNA polymerases by acting as cofactor. The concentration of calcium showed Solanum melongena fruit could better aid the regulation of homeostatic balance than Cucumis sativus fruit. Calcium is known to promote the proper functioning of bones, muscles, bodily cells and nerves.

Manganese, copper, zinc and chromium are reported by Imo et al. (2019) to be important micro-minerals which are required by certain enzymes by acting as co-factors required for some pathways or biochemical processes. This means that consumption of the two fruits used in this study have the potency of supplying these minerals which are required in minute quantity. Though their levels in both fruits (table 3) are low, it is believed to be appreciable since they are required in small amount and excessive accumulation in the animal body may cause adverse effect. It has been reported that certain disease conditions could be caused as a result of deficiency of the 
microminerals in human. However, they may cause disruption of homeostatic balance when consumed in excess (Imo et al., 2019).

The level of iron in Solanum melongena fruit showed it is slightly a better source of iron than Cucumis sativus fruit. The cytochromes have been reported to require iron as a crucial component. Iron is needed for the production of haemoglobin which is required for proper oxygen transport, cellular respiration and the functioning of red blood cell (Imo et al., 2019). Therefore, consumption of Solanum melongena fruit may aid better in these functions when compared to Cucumis sativus fruit. However, consumption of the two fruits may positively support the immune system.

\section{Conclusion}

The fruits of Solanum melongena and Cucumis sativus contain different important chemical constituents which possess various biological, nutritional and physiological functions. Consumption of the two fruits may positively support the human immune system and are encouraged since they possess various important chemical constituents and certain mineral elements that are essential in general medicine and nutrition.

\section{Conflict of interest statement}

Authors declare that they have no conflict of interest.

\section{References}

Abbey, B.W., Nwachoko, N., Ikiroma, G.N., 2017. Nutritional value of cucumber cultivated in three selected states of Nigeria. Biochem. Anal. Biochem. 6(3), 328.

Adeyeye, E. I., Fagbohun, E.D. (2006). Nutritional Studies of Seven Varieties of Nigerian Garden Egg Fruit. J. Appl. Environ. Sci. 2(1), 129-135.
Agatemor, U. M., Nwodo, O. F. C., Anosike, C. A., 2018. Phytochemical and proximate composition of cucumber (Cucumis sativus) fruit from Nsukka, Nigeria. Afr. J. Biotechnol. 17(38), 1215-1219.

Agoreyo, B. O., Obansa, E. S., Obanor, E. O., 2012. Comparative nutritional and phytochemical analyses of two varieties of Solanum melongena. Science World J. 7(1), 5-8.

AOAC (1990). Official Methods of Analysis, 15th edition. Arlington, VA, USA.

AOAC (2005). Official Method of Analysis, 18th edition. Arlington, VA, USA.

AOAC (2010). Official methods of proximate analysis. AOAC International, Gaithersburg, MD., p.15.

Auta, R., Ali, I. (2011). Nutritional and Chemical Evaluation of Solanum incanum (Bitter Garden Egg). International Journal of Tropical Medicine and Public Health. 1(1): 96-107.

Bello, M.O., Owoeye, G., Abdul Hammed, M., Yekeen, T.A. (2014). Characterization of Gourd Fruits (Cucurbitaceae) For Dietary Values and Anti-Nutrient Constituents. Journal of Pharmaceutical, Biological and Chemical Science, 5(4). 416-424.

Burdock, G.A., Crabin, I.G. (2007). Safety assessment of myristic acid as a food ingredient. Food Chem Toxicol., 45(4): 517529. DOI: 10.1016/j.fct.2006.10.009.

Chinedu, S.N., Olasumbo, A.C., Eboji, O.K., Emiloju, O.C., Arinola, O.K., Dania D.I. (2011). Proximate and Phytochemical Analyses of Solanum aethiopicum L. and Solanum macrocarpon L. Fruits. Research Journal of Chemical Sciences, 1(3): 63-71.

Dahinog, M., Rafols E.D., Laspinas, V., Lau, H.K.F., Boyde, T.R.C. (1982-1983). Amino acid composition of vegetable and fruits from the Philippines. The Bulletine of the Philippine. 4 \& 5 (1): 31-39.

Dalziel, J.M. (1937). The Useful Plants of West Tropical Africa (New York: Longman) 1st edn., 433-435. 
Diab, R., Mounayar, A., Maalouf, E., Chahine, R. (2011). Beneficial effects of Solanum melongena (Solanaceae) peduncles extracts, in periodontal diseases. Journal of Medicinal Plants Research, 5(11): 23092315.

Eze, S.O., Kanu, C.Q. (2014). Phytochemical and Nutritive Composition Analysis of Solanum aetiopicum. Journal of Pharmaceutical and Scientific Innovation, 3(4): 358-362.

Faik, A. A., Nesrin, C., Mujgan, T., Petr, T., Pavel, J., Gerald, S., Huseyin, I. (2015). comparison of nutrient content in fruit of commercial cultivars of eggplant (Solanum melongena L.). Polish Journal of Food Nutrition Science, 65(4): 251-259.

Freeze, H. H., Sharma, V. (2010). Metabolic manipulation of glycosylation disorders in humans and animal models. Seminars in Cell \& Developmental Biology, 21(6): 655662. doi:10.1016/j.semcdb.2010.03.011.

Gbile, Z. O., Adesina, S.K. (1988). Nigerian solanum species of economic importance. Ann. Missouri Bot. Garden. 75(3), 862-865. Gerrit, M. W, Ben F.M.K., Michiel, C.H., Hendrik, P., Marinus, V. (2014). Lactose and Derivatives. Ullmann's Encyclopedia of Industrial Chemistry. Ullmann's Encyclopedia of Industrial Chemistry. Wiley-VCH. pp. 1-9.

Giannini, A. J., Slaby, A. E., Giannini, M. C. (1982). The Handbook of Overdose and Detoxification Emergencies. New Hyde Park, NY. Medical Examination Publishing Co., pp.48-50.

Haynes, W. M. (2010). Handbook of Chemistry and Physics (91 ed.). Boca Raton, Florida: CRC Press. p. 3-248.

Heidari, H., Kamalinejad, M., Noubarani, M., Jafarian, I., Adiban H., Eskandari, M.R. (2016) Protective Mechanisms of Cucumis Sativus in Diabetes Related Models of Oxidative Stress and Carbonyl Stress. BioImpacts. 6(1): 33-39.

Hina, S., Anam, W. (2017). A review on cucumber (Cucumis sativus). Int. J.
Technical Res. Sci. 2(6), 402.

Hornung, B., Amtmann, E., Sauer, G. (1992). Medium chain length fatty acids stimulate triacylglycerol synthesis in tissue culture cells. Biochem Pharmacol., 43(2): 175-181.

Hunt, D. E., Narkates, A. J. (1971). Effect of Actinobolin on Nucleic Acid and Protein Synthesis in Streptococcus faecalis. J. Dental Res. 50(6), 1610-1615.

Imo, C., Ezeonu, C.S., Imo, N.G., Anigbo, C.J. (2018). Proximate, mineral and phytochemical composition of Cocos nucifera nut. Asian J. Biochem., 13: 9-14.

Imo, C., Uhegbu, F.O., Arowora, K.A., Ezeonu, C.S., Opara, I., Nwaogwugwu, C.J., Anigbo, C.J. (2019). Chemical Composition of Cyperus esculentus nut and Phoenix dactylifera fruit. African Journal of Biotechnology, 18(19): 408-415. DOI: 10.5897/AJB2018.16551.

Imo, C., Yakubu, O.E., Imo, N.G., Udegbunam, I.S., Onukwugha, O.J. (2018). Chemical composition of Xylopia aethiopica fruits. American Journal of Physiology, Biochemistry and Pharmacology, 7(2): 4853.

Irda, F., Siti, W., Komar, R. (2017). Phytochemical content and antioxidant potential of different organs of eggplant (solanum melongena 1.) grown in west java-indonesia. Asian Journal Pharmaceutical and Clinical Research, 10(8): 144-149.

Ito, H., Ueno, H., Kikuzaki, H. (2017). Free Amino Acid Composition for Fruits. Journal of Nutrition and Dietetic Practice, 1: $1-5$.

James, F. B. (2012). Acrylonitrile. Ullmann's Encyclopedia of Industrial Chemistry, Weinheim: Wiley-VCH. DOI: 10.1002/14356007.a01_177.pub3.

Jose, R.S., Sanchez, M.C., Camara, M.M., Prohens, J. (2013). Composition of Eggplant Cultivars of the Occidental Type and Implications for the Improvement of Nutritional and Functional Quality. International Journal of Food Science and 
Technology. 2013: 1-9

Juan, C. D. (2015). Eggplant (Solanum melongena L.) plant growth and fruit yield as affected by drip irrigation rate. Hortscience, 50(11): 1709-1714.

Karam, F., Saliba, R., Skaf, S., Breidy, J., Rouphael, Y., Balendonck, J. (2011). Yield and water use of eggplants (Solanum melongena L.) under full and deficit irrigation regimes. Agricultural Water Management, 98: 1307-1316.

Kumaraswamy, L. (2016). Cucumber-A Natural Medicine and its Therapeutic Potential. Recent Progress in Medicinal Plants. 43:1-8.

Lewis, R.J. Sr. (2001). Hawley's Condensed Chemical Dictionary 14th Edition. John Wiley \& Sons, Inc. New York, NY, pp. $472,927$.

Lewis, R.J. Sr. (2007). Hawley's Condensed Chemical Dictionary 15th Edition. John Wiley \& Sons, Inc. New York, NY, p. 868.

Li, Y.O., Kamarek, R,A. (2017). Dietary Fibre Basics: Health, Nutrition, Analysis and Application. Food Quality and Safety, 1(1). 47-59.

Marrugo, L.Y., Severiche, S. C., Jaimes, M.J. (2017). Development of a food product type based sauce eggplant (Solanum melongena). International Journal of ChemTech Research, 10(10): 567-571.

Mbah, U.O., Egbuonu, A.C., Achi, N.K., Nwanne, I.D., Jeremiah, O. (2018). Hepatoprotective Potentials of Ethanolic Extract of Solanum melongena Linn Fruit on Monosodium Glutamate- Intoxicated Rats' and Liver Section Histology. International Blood Research and Reviews, 9(1): 1-9.

Mohammad, H.A., Hossein, A., Hamide, F., Atefe, A., Sajede, K. (2010). Responses of eggplant (Solanum melongena 1.) to different rates of nitrogen under field conditions. Journal Central European Agriculture, 11(4): 453-458.

Murad, H., Nyc, M.A. (2016). Evaluating the potential benefits of cucumbers for improved health and skin care. Journal of Aging Research \& Clinical Practice, 5(3): 139-141.

Mutalik, S., Paridhavi, K., Mallikarjuna C. R., Udupa, N. (2003). Antipyretic and analgesic effect of leaves of solanum melongena linn. in rodents. Indian Journal of Pharmacology, 35: 312-315.

Odetola, A.A., Iranloye, Y.O., Akinloye O. (2004). Hypolipidaemic Potentials of Solanummelongena and Solanum gilo on Hypercholesterolemic Rabbits. Pakistan Journal of Nutrition, 3(3): 180-187.

Offor, C.E., Igwe, S.U. (2015). Comparative analysis of the vitamin composition of two different species of garden egg (Solanum aethiopicum and Solanum macrocarpon). World Journal Medical Sciences, 12(3): 274-276.

Ohkubo, M., Kawamoto, H., Ohno, T., Nakano, M., Morishima, H. (1997). Synthesis of NB506, a new anticancer agent. Tetrahedron, 53(2): 585-592. DOI:

10.1002/chin.199718272.

Okoye, N.F. (2013). Proximate Analysis and Protein Solubility of Four Curcubits Found in Nigeria. Pakistan Journal of Nutrition, 12: $20-22$.

Onimisi, A.O., Ovansa, J.U. (2015). Comparative Studies on Nutritional Values of Four Varieties of Cucumber. International Conference on Latest Trends in Food, Biological \& Ecological Sciences, pp. 38-39.

Osei, M. K., Banful, B. C., Osei, K., Oluoch, M. O. (2010). Characterization of African Eggplant for Morphological Characteristics. Journal of Agricultural Science and Technology, 4(3). 33-37.

Osuagwu, G. G. E., Ejikeme, F. O. (2015). The Antimicrobial activity of the leaves of some wild Cucurbitaceae species from SouthEast Nigeria. Human Journals Research, 2(4): 2015.

Paliyath G., Tiwari,K., Sitbon, C., Whitaker, B.D. (2012). Biochemistry of Fruits. Food Biochemistry and Food Processing, Second 
Edition. pp. 533-553.

Prado-Prado, F. J., García-Mera, X., González-

Díaz, H. (2010). Multi-target spectral

moment QSAR versus ANN for

antiparasitic drugs against different

parasite species. Bioorg Med Chem., 18(6):

2225-2231. DOI:

10.1016/j.bmc.2010.01.068.

Raaz, K.M., Mohan, L., Malhotra,J., Updhuay, B., Rani, B. (2014). Invigorating Efficacy of Cucumis Sativas for Healthcare and Radiance. International Journal of Chemistry and Pharmaceutical Sciences, 2(3): 737-744.

Ren, R., Hashimoto, T., Mizuno, M., Takigawa, H., Yoshida, M., Azuma, T., Kanazawa, K. (2013). A lipid peroxidation product 9oxononanoic acid induces phospholipase A2 activity and thromboxane A2 production in human blood. Journal of Clinical Biochemistry and Nutrition 52(3): 228-233. DOI: 10.3164/jcbn.12-110.

Rizvi, S., Raza, S.T., Absar, F.A., Abbas, S., Mahdi, F. (2014). The Role of Vitamin E in Human Health and Some Diseases. Sultan Qaboos University Medical Journal, 14(2): 157-165.

Robert, J. N., Boris, K., Hazel S., Velmurugan, S. (2018). Effectiveness of Cucumis sativus extract versus glucosamine-chondroitin in the management of moderate osteoarthritis: a randomized controlled trial. Clinical Interventions in Aging, 13 2119-2126.

Saeed, H., Waheed, A. (2017). A Review on Cucumber (Cucumis sativus). International Journal of Technical Research \& Science. 2(6): 402-405.

Sharba, A.H.K., Al-Fattahi, Y.A., Askar, F.W. (2011). Synthesis of New Carbohydrate Derivatives Via 1, 3-Dipolarcycloaddition Reaction. Journal of Al-Nahrain University, 14(2): 9S-9S.

Sharmin, R., Khan, M., Akhter, M., Alim., A., Islam, A., Ahmed, M. (2107). Hypoglycemic and hypolipidemic effects of cucumber, white pumpkin and ridge gourd in alloxan induced diabetic rats. Journal Science Research, 5(1): 161-170.

Sihachkr, D., Chaput, M.H., Serraf, L., Ducreux, G. (1993). Regeneration of plants from protoplasts of eggplant (Solanum melongena L.). In: Bajaj, Y.P.S. (Ed.), Biotechnology in Agriculture and Forestry, Plant Protoplasts and Genetic Engineering. Springer, Berlin. pp. 108-122.

Soetan, K.O., Olaiya, C.O., Oyewole, O.E. (2010). The importance of mineral elements for humans, domestic animals and plants: A review. Afr. J. Food Sci., 4: 200-222.

Sood, A., Kaur, P., Gupta, R. (2012). Phytochemical screening and antimicrobial assay of various seeds extract of Cucurbitaceae family. International Journal of Applied Biology and Pharmaceutical Technology, 3(3): 401-409, 2012.

Sotiroudis, G., Melliou, S. E., Chinou, I. (2010). Chemical analysis, antioxidant and antimicrobial activity of three Greek cucumber (Cucumis sativus) cultivars. Journal of Food Biochemistry, 34:61-78.

Varsha, J., Vaibhav, K., Poonam, P. (2014). GC-MS analysis of bioactive compounds in methanolic extract of Holigarna grahamii (wight) Kurz. International Journal of Herbal Medicine, 2(4): 35-39.

Vivek, K.B., Ji-Eun, K., Yong-Ha, P., Sun, C.K. (2017). In vivo pharmacological effectiveness of heat-treated cucumber (Cucumis sativus L.) juice against $\mathrm{CCI}_{4}$ induced detoxification in a rat model. Indian J. Pharmaceut. Education Res. 51(2), 280-287.

Walingo, K. M., 2005. Role of Vitamin C (Ascorbic acid) on human health- A review. Afr. J. Food Agric. Nutr. Develop. 5(1), 1-11. Wallach, D., 1961. Studies on the GABA pathway. I. The inhibition of gammaaminobutyric acid-alpha-ketoglutaric acid transaminase in vitro and in vivo by $\mathrm{U}-$ 7524 (amino-oxyacetic acid). Biochem. Pharmacol. 5(4), 323-331. 
Warrier, P.K., Nambiar, V.P.K., Rammanakutty, C., $1996 . \quad$ Indian Medicinal Plants. Madras (India): Orient Longman Publishers Limited.

Weese, T.L., Bohs L., 2010. Eggplant origins: Out of Africa, into the Orient. Origins of the domesticated eggplant (Solanum melongena). Taxon. 59(1), 49-56.

Zieliński, H., Zielińska, D., 2017. The Naturally
Fermented Sour Pickled Cucumbers: in Fermented Foods in Health and Disease Prevention, ScienceDirect, 2017.

Zong, Y., Wang, J., Yue, G., Feng, L., Song, Z., Song, H., Han, Y., 2005. Traceless liquidphase synthesis of 3-alkylamino-4,5disubstituted-1,2,4-triazoles on polyethylene glycol (PEG). Tetrahedron Lett. 46(31), 5139-5141.

\section{How to cite this article:}

Imo, C., Abu, S. M., Emmanuel, O. P., Yusuf, K. S., 2020. Phytochemical constituents and mineral composition of fruits of Solanum melongena and Cucumis sativus. Int. J. Curr. Res. Biosci. Plant Biol. 7(6), 26-36. doi: https://doi.org/10.20546/ijcrbp.2020.706.003 